\title{
Poplar Forests of the Ob River near the Town of Kolpashevo, Tomsk Region, Russia
}

\author{
Georgy S. Taran*a and Alexander P. Dyachenko ${ }^{\mathrm{b}}$ \\ ${ }^{a}$ West-Siberian Division of V.N. Sukachev Institute of Forest, SB RAS \\ Branch of FRC "Krasnoyarsk Scientific Center" SB RAS \\ Novosibirsk, Russian Federation \\ ${ }^{b}$ Urals State Pedagogical University \\ Yekaterinburg, Russian Federation
}

Received 25.10.2017, received in revised form 07.12.2017, accepted 28.12.2017, published online 12.07.2018

\begin{abstract}
Natural poplar (Populus nigra, Populus alba) forests of the Ob River were studied on the northern border of south taiga subzone (vicinities of the town of Kolpashevo, Kolpashevo district of Tomsk Region, $58^{\circ} 18^{\prime} \mathrm{N}, 82^{\circ} 54^{\prime}$ E) on the floodplain segment formed in 1890-1970. They belong to association Anemonidio dichotomi-Populetum nigrae Taran 1993 (Equiseto hyemalis-Populion nigrae Taran 1997, Salicetalia purpureae Moor 1958, Salicetea purpureae Moor 1958) and 2 subassociations: Anemonidio dichotomi-Populetum nigrae typicum Taran 1993 and Anemonidio dichotomi-Populetum nigrae rubetosum saxatilis Taran subass. nov. The poplar forests were examined from young timber stage of black poplar (Populus nigra) to stage of its total extinction. General direction of the poplar forest succession is expressing in a replacement of black poplar stands by birch ones. On sandy soils, black poplar stands are changed by small-sized Scotch pine ones. At the middle stages of the succession, white poplar (Populus alba) plays a significant role, occasionally along with Populus $\times$ canescens. However, white poplar doesn't form stable stands near the town of Kolpashevo as it grows there at the northern border of its areal in Western Siberia. In studied poplar forests, the average species saturation was 42.4 and 14.4 species per $100 \mathrm{~m}^{2}$ for vascular plants and for mosses respectively. On the whole, 123 species of vascular plants and 34 species of mosses were registered in the poplar forests.
\end{abstract}

Keywords: syntaxonomy, alluvial forests, forest succession, Populus nigra, Populus alba, Populus $\times$ canescens, Kolpashevo Meander, south taiga subzone.

Citation: Taran G.S., Dyachenko A.P. Poplar forests of the Ob River near the town of Kolpashevo, Tomsk Region, Russia. J. Sib. Fed. Univ. Biol., 2020, 13(1), 62-80. DOI: 10.17516/1997-1389-0064

(C) Siberian Federal University. All rights reserved

This work is licensed under a Creative Commons Attribution-NonCommercial 4.0 International License (CC BY-NC 4.0).

* Corresponding author E-mail address: gtaran@mail.ru 


\title{
Тополевые леса реки Оби у города Колпашево (Томская область, Россия)
}

\author{
Г.С. Таран ${ }^{\mathrm{a}}$, А.П. Дьяченко \\ азападно-Сибирское отделение Института леса \\ им. В.Н. Сукачева СО РАН- \\ филиал ФИЦ «Красноярский научный центр СО РАН» \\ Российская Федерация, Новосибирск \\ ${ }^{6} У$ ральский государственный педагогический университет \\ Российская Федераиия, Екатеринбург
}

\begin{abstract}
Аннотация. Естественные тополевые (Populus nigra, Populus alba) леса р. Оби изучены на северной границе подзоны южной тайги (окрестности г. Колпашево Колпашевского района Томской области, $58^{\circ} 18^{\prime}$ с. ш. и $82^{\circ} 54^{\prime}$ в. д.) на сегменте поймы, сформированном в 1890 1970 гг. Они относятся к ассоциации Anemonidio dichotomi-Populetum nigrae Taran 1993 (союз Equiseto hyemalis-Populion nigrae Taran 1997, порядок Salicetalia purpureae Moor 1958, класс Salicetea purpureae Moor 1958) и двум субассоциациям: Anemonidio dichotomi-Populetum nigrae typicum Taran 1993 и Anemonidio dichotomi-Populetum nigrae rubetosum saxatilis Taran subass. nov. Эти леса рассмотрены от стадии приспевания осокоря (Роpulus nigra) до его полного выпадения из состава древостоя. Общее направление сукцессии тополевых лесов выражается в смене осокорников березняками. На легких песчаных грунтах осокорники замещаются мелкоконтурными сосняками. На средних стадиях сукцессии значительную роль играет тополь белый (Populus alba), иногда вместе с тополем сереющим (Populus $\times$ canescens). У г. Колпашево тополь белый не образует устойчивых ценозов, так как находится на северной границе своего ареала в Западной Сибири. В среднем в изученных тополевых лесах на 100 м $^{2}$ отмечается 42,4 вида сосудистых растений и 14,4 видов мхов. Всего в них зафиксировано 123 вида сосудистых и 34 вида мхов.
\end{abstract}

Ключевые слова: синтаксономия, аллювиальные леса, лесные сукцессии, Populus nigra, Populus alba, Populus $\times$ canescens, Колпашевская излучина, подзона южной тайги.

Цитирование: Таран, Г.С. Тополевые леса реки Оби у города Колпашево (Томская область, Россия) / Г.С. Таран, А.П. Дьяченко // Журн. Сиб. федер. ун-та. Биология, 2020. 13(1). С. 62-80. DOI: 10.17516/1997-1389-0064

\section{Введение}

Тополевые леса р. Оби в синтаксономическом отношении наиболее изучены в подзоне средней тайги, включая север Томской области (Таран, 1993, 2014, 2015a; Таран и др., 2004; Таран, Тюрин, 2006). В центральной части области об этих лесах мало что известно. Некоторые общие сведения при- водят геоботаники и лесоведы (Львов, 1963; Алехина, 1970, 1971; Боотсма и др., 1995). В последней работе в столбце синоптической таблицы совокупно характеризуется ценофлора ветловых и осокоревых лесов (74 вида сосудистых и 2 вида мхов), произрастающих на южной границе подзоны южной тайги (с. Красный Яр Кривошеинского 
р-на Томской области). Тем не менее, в этой ценофлоре не указаны многие виды, играющие важную роль в зональном различении обских топольников.

Цель настоящей статьи - дать детальную характеристику тополевым лесам р. Оби, изученным в центральной части Томской области.

\section{Материалы и методы}

В природном отношении район исследований располагается на северной границе подзоны южной тайги (Ильина и др., 1985). Материал собран в августе-сентябре 2009 г. на левом берегу Оби напротив г. Колпашево Колпашевского р-на Томской области. Ключевой полигон был заложен на вершине крупного массива, Колпашевской излучины Оби, на сегменте поймы, возникшем в $1890-$ 1970 гг. (Zavadskii et al., 2013: рис. 2). Высокие пойменные гривы, одно из наиболее характерных местообитаний тополевых лесов, на Колпашевской излучине затопляются в среднем раз в четыре года (Николаев, 2012). Координаты центральной точки ключевого полигона $-58^{\circ} 17^{\prime} 27,8^{\prime \prime}$ с. ш., $82^{\circ} 58^{\prime} 03,2^{\prime \prime}$ в. д.

При геоботаническом описании пойменных лесов использовалось два подхода. Некоторые типичные насаждения характеризовались более детально. Общее проективное покрытие (ОПП) крон определялось как для древесного полога в целом, так и по ярусам. Высота (выс.) и состав древостоя оценивались глазомерно. Периметры деревьев на учетной площадке (УП) замерялись рулеткой и затем пересчитывались в диаметры (Ø). Поскольку УП захватывали небольшое количество стволов (стандартный

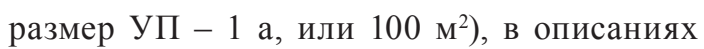
указываются не таксационные, а средние арифметические диаметры. Количественный учет подроста деревьев в подлеске (до высоты 6 м) не проводился. При указании состава древостоя в тексте и таблицах используются следующие обозначения: Й $_{6}$ ветла (Salix alba); $\mathrm{T}_{\text {ч }}$ - осокорь (Populus nigra); $\mathrm{T}_{6}$ - тополь белый (Populus alba); $\mathrm{T}_{\mathrm{c}}$ - тополь сереющий (Populus $\times$ canescens); Б - береза (Betula pendula, B. pubescens); $\mathrm{C}$ - сосна (Pinus sylvestris); К - кедр (Pinus sibirica); Оc - осина (Populus tremula); Ч - черемуха (Padus avium): когда она отмечалась не в подлеске, а во II ярусе древостоя.

УП имели квадратную либо прямоугольную форму, длина сторон отмерялась рулеткой, вершины УП фиксировались вешками. Четкое обозначение границ гарантировало, что на УП будет осмотрена каждая четверть квадратного метра поверхности. Проективное покрытие (ПП) сосудистых видов оценивалось в процентах. Низкие значения ПП указывались баллами: «г» - не более $0,01 \%$, «+»- более 0,01 , но менее $0,3 \%$. Оценивалось ПП травостоя общее и по агроботаническим группам: злаки, осоки, бобовые, разнотравье. Оценивалось ОПП напочвенных мхов, проводились их детальные сборы: отдельно по ярусам D (почва, валеж, подстилка, гниющие пни, земляные муравейники) и Е (стволы деревьев и кустарников, включая комлевую часть). Автор всех описаний и коллектор мхов - Г.С. Таран. Сборы мхов обработал А.П. Дьяченко (Дьяченко, Таран, 2011), образец печеночника Aneura pinguis (L.) Dum. определил В.А. Бакалин.

На обследованном сегменте Колпашевской излучины развернулась широкая панорама естественной сукцессии пойменных лесов, которая в топольниках начинается поселением осокоря. Различные варианты дальнейших смен осокоря в растительном покрове выражаются в постепенном распаде его полога и временном формировании более или менее сомкнутых насаждений, 
сложенных породами-преемниками. По недостатку времени древостой таких переходных ценозов описывался по упрощенной схеме. Визуально определялась высота древостоя и основных древесных пород, глазомерно выделялось дерево среднего диаметра, рулеткой замерялся его периметр. Фиксировались ОПП древесного яруса, подлеска и травостоя. ПП видов оценивалось в баллах: «+»- менее $1 \%$, «1» $-1-5 \%$, «2»-6-12\%, «3»-13-25\%, «4»-26-50\%, «5»- 51-75\%, «6»-76-100\%. Размер УП $\left(100 \mathrm{~m}^{2}\right)$ задавался визуально. Эти несколько упрощенные описания также приводятся в статье, поскольку за четверть века работы на Оби смены топольников в такой масштабной и разнообразной форме на относительно небольшом участке Г.С. Тараном наблюдались впервые.

Обработка описаний велась методом табличной сортировки на основе интегрированной ботанической информационной системы IBIS (Зверев, 2007). Результаты классификации растительности представлены в соответствии с методическими подходами направления Браун-Бланке (Weber et al., 2000). Виды сосудистых растений указываются по С.К. Черепанову (1995), мхов - по M.S. Ignatov et al. (2006).

\section{Результаты и обсуждение}

Тополевые леса Колпашевской излучины относятся к ассоциации (асc.) Anemonidio dichotomi-Populetum nigrae Taran 1993, входящей в союз Equiseto hyemalis-Populion nigrae Taran 1997, порядок Salicetalia purpureae Moor 1958, класс Salicetea purpureae Moor 1958 (Таран, 1993, 2014). Диагностические виды ассоциации: Populus nigra (доминант), Anemonidium dichotomum, Lathyrus palustris, Lathyrus pilosus, Ptarmica cartilaginea (табл. 1).
Оп. 1-2 относятся к субассоциации (субасс.) Anemonidio dichotomi-Populetum nigrae typicum Taran 1993, характерной для подзоны средней тайги (Таран, 2014). Осокорник чиново-осоковый (оп. 1; состав древостоя $10 \mathrm{~T}_{\text {ч) }}$, занимал площадь 3 ара на днище хорошо выраженного в рельефе плоского сухого межгривного понижения. Осокорь имел несколько угнетенный вид. Это редкий вариант осокорника. На севере области ни осоки, ни бобовые под пологом осокоря в качестве содоминантов травостоя в последние десятилетия не отмечались (Таран, 2014).

Осокорник разнотравный (оп. 2) в виде довольно обширного контура занимал чуть вогнутый участок на гребне широкой пойменной гривы. Древостой $\left(8 \mathrm{~T}_{\text {ч }} 2 \mathrm{~T}_{6}\right)$ и травостой находились в очень хорошем состоянии. Оп. 2 характеризуется высокой видовой насыщенностью (ВН): 48 видов на ар (вид/а) против 27-37 вид/а на севере области (Таран, 2014). Кроме того, на севере области ни разу не отмечался тополь белый (Таран, 2005a).

Большая часть топольников Колпашевской излучины (оп. 3-10) содержит группу видов, которая отличает их от осокорников подзоны средней тайги. На этом основании южнотаежные топольники р. Оби описываются в ранге новой субассоциации:

\section{Anemonidio dichotomi-Populetum nigrae} rubetosum saxatilis Taran subass. nov. hoc loco. Номенклатурный тип (holotypus) - оп. 5* в табл. 1: оп. 20 ГТ, 20.08.2009, окрестности г. Колпашево Колпашевского района Томской области, $58^{\circ} 17^{\prime} 27,8^{\prime \prime}$ с. ш. и $82^{\circ} 58^{\prime} 03,2^{\prime \prime}$ в. д., пойма р. Оби, край широкой пойменной гривы, открытый в межгривное понижение; площадь описания 100 м², автор Г.С. Таран. Диагностические виды: Rubus saxatilis, Rosa acicularis, Crataegus sanguinea, Agrimonia pilosa. Последние три вида достаточно характерны для топольников верхней Оби (Таран, 
Таблица 1. Асc. Anemonidio dichotomi-Populetum nigrae Taran 1993: cубасc. A. d.-P. n. typicum Taran 1993 (1-2) и $\boldsymbol{A}$. d.-P. n. rubetosum saxatilis Taran subass. nov. (3-10)

Table 1. Ass. Anemonidio dichotomi-Populetum nigrae Taran 1993: subass. A. d.-P. n. typicum Taran 1993 (1-2) and $\boldsymbol{A}$. d.-P. $\boldsymbol{n}$. rubetosum saxatilis Taran subass. nov. (3-10)

\begin{tabular}{|c|c|c|c|c|c|c|c|c|c|c|c|}
\hline Номер описания & 1 & 2 & 3 & 4 & $5^{*}$ & 6 & 7 & 8 & 9 & 10 & $\Pi_{3-10}$ \\
\hline Близость к Оби, ранг* & 13 & 5 & 4 & 10 & 14 & 16 & 17 & 20 & 21 & 0 & \\
\hline Форма поверхности УП & вог & вог & нак & вог & нак & нак & нак & выг & выг & выг & \\
\hline Площадь описания, м² & 100 & 100 & 100 & 100 & 100 & 100 & 100 & 100 & 100 & 100 & \\
\hline Возрастное состояние $\mathrm{T}_{\mathrm{q}}$ & спе & спе & спе & пер & спе & спе & пер & пер & пер & пер & \\
\hline ОПП древостоя, А1+А2, \% & 25 & 30 & 60 & 20 & 25 & 35 & 30 & 50 & 60 & 70 & \\
\hline ОПП древостоя, А1, \% & 25 & 30 & 25 & 20 & 25 & 35 & 20 & 50 & 40 & 70 & \\
\hline ОПП древостоя, А2, \% & 0 & 2 & 40 & + & 2 & 4 & 15 & 5 & 25 & 10 & \\
\hline Высота $\mathrm{T}_{\text {ч }}$ (A1), м & 20 & 25 & 22 & 25 & 22 & 24 & 26 & 28 & 27 & 27 & \\
\hline Число стволов $\mathrm{T}_{\text {ч }}$ (A1) & 8 & 4 & 6 & 5 & 8 & 7 & нд & 6 & 1 & 3 & \\
\hline Средний Ø Т ч $(\mathrm{A} 1)$, см & 30 & 35 & 32 & 39 & 35 & 37 & 38 & 52 & 57 & 60 & \\
\hline Максим. Ø Т ( $(\mathrm{A} 1)$, см & 39 & 36 & 46 & 53 & 51 & 44 & нд & 66 & 57 & 78 & \\
\hline Высота $\mathrm{T}_{\text {ч }}(\mathrm{A} 2), \mathrm{m}$ & - & 9 & 12 & - & - & 10 & - & - & - & - & \\
\hline Число стволов $\mathrm{T}_{\text {ч }}$ (A2) & - & 1 & 4 & - & - & 2 & - & - & - & - & \\
\hline Средний Ø Т ч (A2), см & - & 10 & 11 & - & - & 14 & - & - & - & - & \\
\hline Максим. Ø Т ч (A2), см & - & 10 & 17 & - & - & 17 & - & - & - & - & \\
\hline Высота Б, (A1), м & - & - & - & - & - & - & - & - & 25 & 24 & \\
\hline Число стволов Б (А1) & - & - & - & - & - & - & - & - & 2 & 6 & \\
\hline Средний Ø Б (А1), см & - & - & - & - & - & - & - & - & 32 & 35 & \\
\hline Максим. Ø Б (А1), см & - & - & - & - & - & - & - & - & 37 & 46 & \\
\hline Высота Б (А2), м & - & 11 & 10 & 12 & 14 & - & 15 & - & 10 & 10 & \\
\hline Число стволов Б (А2)** & - & 1 & 10 & (1) & (1) & - & нд & - & 2 & 6 & \\
\hline Средний Ø Б (А2), см & - & 9 & 8 & 15 & 18 & - & 17 & - & 14 & 12 & \\
\hline Максим. Ø Б (А2), см & - & 9 & 13 & 15 & 18 & - & 23 & - & 19 & 16 & \\
\hline Прочие древесные породы & - & $\mathrm{T}_{6}$ & $\mathrm{U}_{6}$ & - & - & K & $\mathrm{T}_{6}$ & $\mathrm{U}_{6}$ & $\mathrm{~T}_{6}$ & Ч & \\
\hline Высота, м & - & 25 & 18 & - & - & 11 & 26 & 10 & 10 & 10 & \\
\hline Число стволов & - & 1 & (1) & - & - & 1 & нд & 2 & 3 & 3 & \\
\hline Средний Ø, см & - & 38 & 24 & - & - & 20 & 39 & 29 & 13 & 11 & \\
\hline Максимальный Ø, см & - & 38 & 24 & - & - & 20 & нд & 32 & 14 & 12 & \\
\hline ОПП подлеска, \% & 3 & 15 & 15 & 40 & 60 & 50 & 50 & 60 & 25 & 20 & \\
\hline ОПП травостоя, \% & 40 & 50 & 15 & 60 & 30 & 50 & 30 & 20 & 10 & 40 & \\
\hline ОПП злаков, \% & 2 & 2 & + & 5 & 1 & + & 2 & 0,3 & 2 & 7 & \\
\hline ОПП осок, \% & 20 & 3 & + & 2 & + & + & 1 & 0 & + & + & \\
\hline ОПП бобовых, \% & 15 & + & $\mathrm{r}$ & 3 & 1 & + & 0,5 & 0 & + & + & \\
\hline ОПП разнотравья, \% & 8 & 50 & 15 & 55 & 30 & 50 & 30 & 20 & 8 & 35 & \\
\hline ОПП мхов, \% & + & + & 0,5 & 1 & 3 & 1 & 2 & 1 & 1 & 0,5 & \\
\hline Число видов сосудистых & 32 & 48 & 49 & 41 & 57 & 45 & 48 & 32 & 50 & 40 & \\
\hline Число видов мхов & 8 & 13 & 17 & 14 & 14 & 23 & нд & 12 & нд & нд & \\
\hline \multicolumn{12}{|c|}{ Породы-доминанты } \\
\hline A Populus nigra & 25 & 25 & 30 & 20 & 25 & 35 & 5 & 50 & 10 & 30 & $\mathrm{~V}$ \\
\hline A Betula pendula & . & . & . & + & 2 & . & 15 & . & 50 & 45 & III \\
\hline B Betula pendula & . & . & . & 0,5 & + & . & . & . & + & 3 & III \\
\hline A Populus alba & . & 7 & . & . & . & . & 15 & . & 5 & . & II \\
\hline A Betula pubescens & . & 1 & 35 & . & . & . & . & . & . & 5 & II \\
\hline B Betula pubescens & . & . & 10 & . & . & . & . & . & . & . & I \\
\hline
\end{tabular}


Продолжение табл. 1

Continued Table 1

\begin{tabular}{|c|c|c|c|c|c|c|c|c|c|c|c|}
\hline Номер описания & 1 & 2 & 3 & 4 & $5^{*}$ & 6 & 7 & 8 & 9 & 10 & $\Pi_{3-10}$ \\
\hline \multicolumn{12}{|c|}{ Д. в. acc. Anemonidio dichotomi-Populetum nigrae } \\
\hline Anemonidium dichotomum & 1 & 7 & + & 7 & 1 & 1 & 5 & . & 3 & 5 & $\mathrm{~V}$ \\
\hline Ptarmica cartilaginea & + & . & $\mathrm{r}$ & . & $\mathrm{r}$ & . & 0,5 & + & + & + & IV \\
\hline Lathyrus palustris & 15 & + & . & . & + & . & . & . & . & . & I \\
\hline \multicolumn{12}{|c|}{ Д. в. субасс. A. d.-P. n. rubetosum saxatilis } \\
\hline B Rosa acicularis & . & $\cdot$ & 2 & 0,5 & 3 & 2 & 1 & 40 & 3 & + & $\mathrm{V}$ \\
\hline Rubus saxatilis & . & . & 3 & 20 & 15 & 40 & 15 & 15 & + & . & $\mathrm{V}$ \\
\hline B Crataegus sanguinea & . & $\cdot$ & . & 2 & 1 & 0,5 & 1 & 1 & + & 1 & $\mathrm{~V}$ \\
\hline Agrimonia pilosa & . & $\cdot$ & + & . & 7 & 7 & 5 & + & + & . & IV \\
\hline \multicolumn{12}{|c|}{ Д. в. союза Equiseto hyemalis-Populion nigrae } \\
\hline B Ribes hispidulum & . & + & 10 & 3 & 1 & 3 & 1 & 10 & 10 & 1 & $\mathrm{~V}$ \\
\hline B Rosa majalis & . & 2 & + & 2 & + & + & 1 & 0,5 & 1 & 3 & $\mathrm{~V}$ \\
\hline Equisetum arvense & + & + & + & + & + & + & + & + & 0,5 & . & $\mathrm{V}$ \\
\hline B Swida alba & . & 4 & + & + & 5 & . & 2 & 5 & . & 5 & IV \\
\hline
\end{tabular}

Lysimachia vulgaris

Poa palustris

A2, B Salix dasyclados

A, B( $\left(^{B}\right)$ Salix alba

Phalaroides arundinacea

Stachys palustris

Filipendula ulmaria

Agrostis gigantea

Poa angustifolia

Vicia cracca

Veronica longifolia

Vicia sepium

Kadenia dubia

Calamagrostis epigeios

Lactuca sibirica

Hieracium umbellatum

Scutellaria galericulata

B Ribes nigrum

B Frangula alnus

Carex cespitosa

Galium palustre

B, A2( $\left(^{\mathrm{A}}\right)$ Padus avium

Glechoma hederacea

B, C Viburnum opulus

Galium boreale

Elytrigia repens

Ranunculus repens

B Malus baccata

Lathyrus pratensis

Д. в. класса Salicetea purpureae

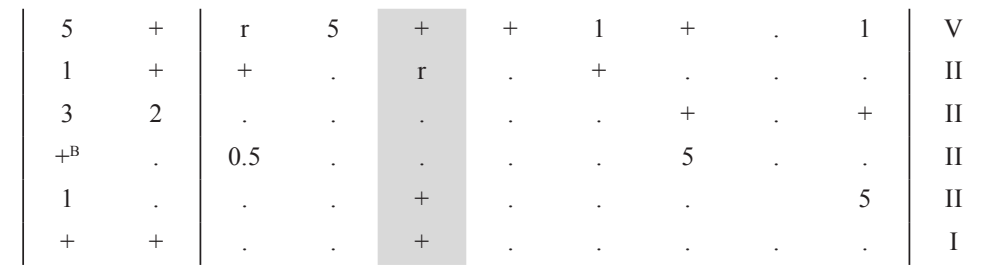

Д. в. класса Brachypodio pinnati-Betuletea pendulae

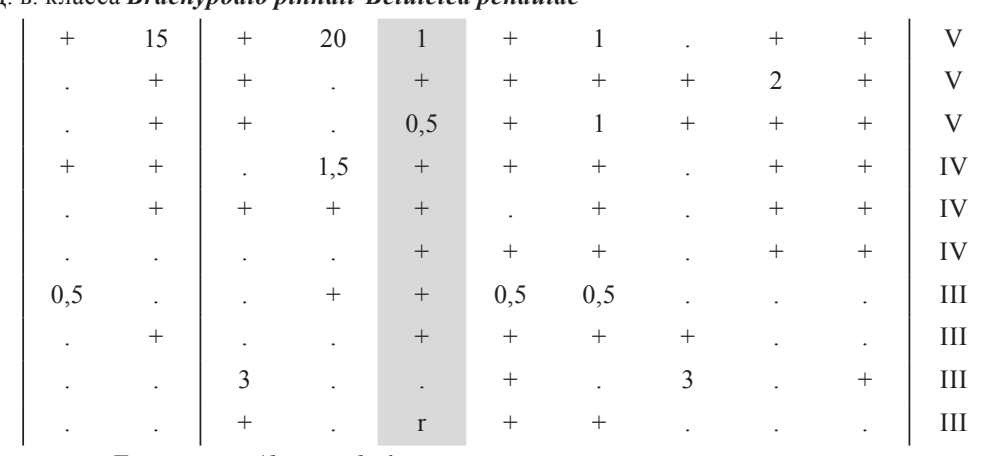

Д. в. класса Alnetea glutinosae

\begin{tabular}{cc|cccccccc|c}
+ & + & + & $\mathrm{r}$ & + & + & + & + & + & + & $\mathrm{V}$ \\
$\cdot$ & 1 & 0,5 & 0,5 & + & + & 0,5 & 1 & 2 & 1 & $\mathrm{~V}$ \\
$\mathrm{rj}$ & 3 & + & 30 & 45 & 45 & 40 &. & 2 & $\cdot$ & $\mathrm{IV}$ \\
+ & 1 & + & 0,3 & + &. & 0,5 &. & + & + & $\mathrm{IV}$ \\
1 & + &. & $\mathrm{r}$ &. &. &. &. & + & + & $\mathrm{II}$
\end{tabular}

Прочие виды сосудистых

\begin{tabular}{|cc|cccccccc|c}
$\cdot$ & + & 1 & + & 5 & 2 & 5 & 10 & 10 & $10^{\mathrm{A}}$ & $\mathrm{V}$ \\
$\cdot$ & 20 & + & + & 3 & 5 & 3 & + & 2 & 3 & $\mathrm{~V}$ \\
$\cdot$ & 3 & 0,5 & + & 2 & + & 1 & 1 & 1 & + & $\mathrm{V}$ \\
1 & 1 & + & 3 & + & + & 0,5 &. & + & + & $\mathrm{V}$ \\
$\cdot$ & + & + &. & + & + & + & + & + & 1 & $\mathrm{~V}$ \\
$\mathrm{r}$ & 3 & 8 & + & + & + & + &. & 1 &. & $\mathrm{IV}$ \\
$\cdot$ & + & $\cdot$ & 1 & 2 & + & 0,5 &. & + & + & $\mathrm{IV}$ \\
$\cdot$ & + & $\mathrm{r}$ & 1,5 & + & + & + &. & + &. & $\mathrm{IV}$
\end{tabular} 
Продолжение табл. 1

Continued Table 1

\begin{tabular}{|c|c|c|c|c|c|c|c|c|c|c|c|}
\hline Номер описания & 1 & 2 & 3 & 4 & $5^{*}$ & 6 & 7 & 8 & 9 & 10 & $\Pi_{3-10}$ \\
\hline Equisetum pratense & . & + & . & 1 & 3 & 1 & . & + & . & 20 & IV \\
\hline Carex praecox & . & 2 & $\mathrm{r}$ & 1,7 & + & + & 0,5 & . & . & . & IV \\
\hline B Sorbus sibirica & . & . & 0,5 & . & 1 & 0,5 & 0,5 & + & + & . & IV \\
\hline Pyrola rotundifolia & . & . & 1 & . & + & $\mathrm{r}$ & + & + & . & . & IV \\
\hline Orthilia secunda & . & . & + & . & . & $\mathrm{r}$ & + & + & + & . & IV \\
\hline Rumex confertus & . & 1 & . & 0,5 & 0,5 & . & + & . & + & . & III \\
\hline Bromopsis inermis & . & + & . & . & $\mathrm{r}$ & . & . & + & + & 1 & III \\
\hline Prunella vulgaris & . & + & + & . & + & $\mathrm{r}$ & . & . & + & . & III \\
\hline Ranunculus auricomus & . & . & $\mathrm{r}$ & + & . & $\mathrm{r}$ & . & . & + & . & III \\
\hline Ranunculus polyanthemos & . & . & + & . & + & $\mathrm{r}$ & . & . & + & . & III \\
\hline Stellaria palustris & $\mathrm{r}$ & $\mathrm{r}$ & . & $\mathrm{r}$ & . & . & . & . & + & + & II \\
\hline Thalictrum flavum & + & 2 & . & 1 & + & . & . & . & . & . & II \\
\hline Lythrum salicaria & + & + & . & + & + & . & . & . & . & . & II \\
\hline Cacalia hastata & . & . & + & . & . & + & . & . & $\mathrm{r}$ & . & II \\
\hline $\mathrm{B}\left({ }^{\mathrm{B}}\right), \mathrm{C}$ Populus alba & . & . & . & . & . & + & + & . & $++^{\mathrm{B}}$ & . & II \\
\hline Calamagrostis canescens & . & + & . & . & + & . & . & . & . & + & II \\
\hline Taraxacum officinale & . & $\mathrm{r}$ & . & . & + & . & . & . & + & . & II \\
\hline Potentilla anserina & + & + & . & + & . & . & . & . & . & . & I \\
\hline Carex acuta & 17 & + & . & . & . & . & . & . & . & . & - \\
\hline Calamagrostis purpurea & + & + & . & . & . & . & . & . & . & . & - \\
\hline \multicolumn{12}{|c|}{ Мхи } \\
\hline Amblystegium serpens & de & de & de & de & de & de & . & de & . & . & V \\
\hline Leskea polycarpa & de & de & de & de & de & e & . & de & . & . & V \\
\hline Orthotrichum obtusifolium & $\mathrm{e}$ & $\mathrm{e}$ & $\mathrm{e}$ & $\mathrm{e}$ & de & de & . & de & . & . & V \\
\hline Orthotrichum speciosum & $\mathrm{e}$ & $\mathrm{e}$ & $\mathrm{e}$ & $\mathrm{e}$ & de & de & . & de & . & . & V \\
\hline Brachythecium salebrosum & . & de & de & de & de & de & . & de & . & . & V \\
\hline Pylaisia polyantha & $\mathrm{e}$ & . & $\mathrm{e}$ & $\mathrm{e}$ & de & de & . & de & . & . & V \\
\hline Campylidium sommerfeltii & . & $\mathrm{e}$ & de & $\mathrm{d}$ & d & de & . & $\mathrm{d}$ & . & . & V \\
\hline Sanionia uncinata & . & . & d & $\mathrm{d}$ & d & de & . & $\mathrm{d}$ & . & . & V \\
\hline Plagiomnium cuspidatum & . & de & de & . & de & de & . & de & . & . & IV \\
\hline Drepanocladus polygamus & . & e & d & d & d & $\mathrm{d}$ & . & . & . & . & IV \\
\hline Haplocladium microphyllum & . & . & de & d & d & $\mathrm{d}$ & . & . & . & . & IV \\
\hline Sciuro-hypnum oedipodium & . & d & d & . & d & de & . & . & . & . & III \\
\hline Bryum caespiticium & . & . & d & . & . & $\mathrm{d}$ & . & $\mathrm{d}$ & . & . & III \\
\hline Pohlia nutans & . & . & . & . & . & de & . & $\mathrm{d}$ & . & . & II \\
\hline Plagiothecium denticulatum & . & . & e & . & . & $\mathrm{e}$ & . & . & . & . & II \\
\hline Calliergonella lindbergii & de & $\mathrm{d}$ & . & . & de & . & . & . & . & . & I \\
\hline Drepanocladus aduncus & de & $\mathrm{d}$ & . & $\mathrm{d}$ & . & . & . & . & . & . & I \\
\hline Climacium dendroides & e & . & . & $\mathrm{d}$ & . & . & . & . & . & . & I \\
\hline Fissidens bryoides & . & $\mathrm{e}$ & . & $\mathrm{d}$ & . & . & . & . & . & . & I \\
\hline
\end{tabular}

Примечание. Отмечены с невысоким постоянством: сосудистые-Achillea millefolium 3(r), 6(+); Adoxa moschatellina 9(+), 10(+); Amoria repens 1(r); Angelica sylvestris 7(r), 9(0,5); Athyrium filix-femina 3(0,5); Carex atherodes 1(+); Carex vesicaria 1(3); Cirsium setosum 2(3), 3(+); Dryopteris carthusiana 3(+); Equisetum hyemale 2(+), $5^{*}(1)$; Festuca pratensis $3(+), 5^{*}(+)$; Fragaria vesca $7(+)$, 8(r); Geum aleppicum 7(+), 9(+); Humulus lupulus 9(+); Impatiens noli-tangere 8(+); Inula salicina 4(+), 6(+); Maianthemum bifolium 2(+), 6(+); Matteuccia struthiopteris 8(+), 10(3); Mentha arvensis 1(+); Moehringia lateriflora 8(+); Naumburgia thyrsiflora 10(r); Malaxis monophyllos 3(+); Paris quadrifolia 6(r), 9(+); Persicaria amphibia 1(r); Plantago major 4(r), 9(r); Rubus caesius $5^{*}(+)$; A2 Pinus sibirica 6(4); B Pinus sibirica 3(+), 7(+); C Pinus sibirica 9(rj); B Pinus sylvestris 4(+); Poa pratensis 7(+); A2 Populus tremula 10(1); Pyrola minor 3(+); B Salix cinerea 4(+), 9(+); Sanguisorba officinalis 9(+); Serratula wolffi 9(+); Stellaria longifolia 3(r), $10(+)$; Thalictrum minus $9(+)$; Thalictrum simplex $3(+)$, 4(+); Trifolium pratense $1(+)$; Urtica dioica $9(+)$, 10(1); Viola montana $5^{*}(+)$; 
Окончание табл. 1

End Table 1

мхи - Bryum pseudotriquetrum 3(d); Ceratodon purpureus 6(d); Dicranum fuscescens 6(d); Dicranum montanum 6(d); Hylocomium splendens 6(e); Leptodictyum riparium 4(d); Oncophorus wahlenbergii 5*(d); Plagiomnium drummondii 3(d); Pleurozium schreberi 6(d); Polytrichum piliferum 6(d); Pylaisia selwynii 2(e); Sciuro-hypnum reflexum 6(d); Sciuro-hypnum starkei 3(d); Timmia megapolitana 6(e); Zygodon sibiricus 8(e); печеночник (на сырой колоде) - Aneura pinguis 5 *(d). Проективное покрытие мхов не определялось, указана только их ярусная локализация (d, e, de); «d» соответствует D-ярусу, «е» - E-ярусу, «de» - D- и Е-ярусам; постоянство мхов для оп. 3-8 рассчитано на основе 5 оп., где были проведены сборы мхов.

Полевые номера и даты описаний: $\mathbf{1}$ - оп. 21, 21.08.2009; 2 - оп. 26, 24.08.2009; 3 - оп. 27, 25.08.2009; 4 - оп. 25, 24.08.2009; 5* - оп. 20, 20.08.2009; 6 - оп. 18, 16.08.2009; 7 - оп. 47, 14.09.2009; 8 - оп. 14, 15.08.2009; 9 - оп. 12 , $14.08 .2009 ; 10$ - оп. 49 , 16.09.2009.

Условные обозначения. * - Ранг близости к Оби в табл. 1 и 2 означает порядковый номер описания на фитоценотическом профиле, проведенном от берега Оби (ранг 0) к тыльной (наиболее удаленной) части пойменного сегмента (ранг 21). ** Число стволов, взятое в скобки, указывает, что ствол дерева находился за пределами УП, но его крона нависала над УП. $\Pi_{3-10}-$ постоянство видов в оп. 3-10, указанное в баллах: I - 1-20\%, II - 21-40 \%, III - 41-60\%, IV - 61-80 \%, V - 81-100 \%. Форма поверхности УП: вог - вогнутая, нак - наклонная, выг - выгнутая, гор - горизонтальная (ровная); Ø - диаметр; А, A1, A2, В, С - обозначение яруса для деревьев и кустарников, включая подрост (А - древесный ярус, А1 - I ярус, А2 - II ярус древостоя, В - подлесок, С - травяной ярус); D - напочвенный ярус, Е - ярус эпифитов (стволы и основания деревьев и кустарников); «ј»- вид представлен ювенильными экземплярами, например: «гј». Возрастные состояния древостоя из осокоря $\left(\mathrm{T}_{\mathrm{y}}\right)$ - в табл. 1 и 2: при - приспевание, спе - спелость, пер - перестой (начало распада древостоя), рас - интенсивный распад древостоя, сух - сухостой; ред - обширные редины на месте распавшихся осокорников. Д. в. - диагностические виды синтаксонов; нд - нет данных.

1997), тогда как Rubus saxatilis нигде более на Оби с таким высоким постоянством в их составе не отмечалась.

В древостое спелых сообществ субасс. A. d.-P. n. rubetosum saxatilis на первых этапах развития обычно доминирует осокорь (оп. 3-6). В дальнейшем он постепенно замещается тополем белым и особенно березой (оп. 7, 9, 10). Состав древостоя таков: оп. $3-8 \mathrm{~T}_{\mathrm{u}} 2$ Б, оп. $4-10 \mathrm{~T}_{\mathrm{u}}+$ Б, оП. $5^{*}-10 \mathrm{~T}_{\mathrm{u}}+$ Б, оп. $6-10 \mathrm{~T}_{\text {ч }}$ оп. $7-6 \mathrm{~T}_{4} 2 \mathrm{~T}_{6} 2$ Б, оп. $8-10 \mathrm{~T}_{\mathrm{y}}+\mathrm{И}_{6}$,

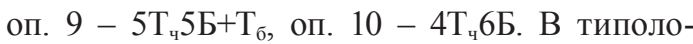
гическом отношении (Алехина, 1970, 1976) все сообщества субасс. $\boldsymbol{A}$. d.-P. $\boldsymbol{n}$. rubetosum saxatilis, представленные в табл. 1, относятся к кустарниково-разнотравной группе типов леса.

В пойменном рельефе и лесном покрове оп. 3-10 занимают следующие варианты местообитаний: оп. 3 - значительный по размеру участок спелого осокорника с обильным подростом березы во II ярусе древостоя и в подлеске; оп. 4 - мелкий (1 а) фрагмент перестойного осокорника, сохранившийся на обширном контуре распавшегося насаждения; оп. 5* - узкая (10-15 м) лента спело- го осокорника, идущего по открытой к межгривному понижению периферии широкой пойменной гривы, занятой березовым лесом; оп. 6 - узкая (15-20 м) полоса спелого осокорника, занимающего аналогичное местообитание с противоположной стороны гребня той же гривы; оп. 7 - перестойный тополевый лес в краевой зоне старой пойменной гривы; оп. 8 - мелкий (1 a) фрагмент перестойного осокорника, сохранившегося на краю гребня широкой пойменной гривы, занятой спелым березовым с примесью перестойных осокорей лесом; 9 - участок березово-осокоревого леса на гребне гривы, наиболее удаленной от русла Оби; оп. 10 - мелкий (1 а) фрагмент осокорево-березового леса на бровке высокого подмываемого берега Оби. Последнее описание сделано выше по течению Оби на значительном удалении от прочих.

Сообщества, которые описывались по упрощенной схеме (табл. 2), также разделяются на две субасс.: $\boldsymbol{A}$. $\boldsymbol{d}$.-P. $\boldsymbol{n}$. typicum (оп. 11-12) и A. d.-P. n. rubetosum saxatilis (оп. 13-22). По возрастному состоянию осокоря и степени его участия в сложении древостоя изученные топольники разделены на несколько возраст- 
ных либо сукцессионных групп: с осокорем приспевающим (оп. 11, 13, 14), перестойным (оп. 16, 17, 22), распадающимся (оп. 15, 18, 20), почти полностью выпавшим и образовавшим редины, занятые лугами и кустарниками (оп. 12, 19), с полностью выпавшим и замещенным породами-преемниками (оп. 21). Охарактеризуем древостой и местообитания описаний из табл. 2.

Оп. 11: приспевающий осокорник $\left(10 \mathrm{~T}_{\mathrm{q}}+\mathrm{И}_{6}\right)$ разнотравный, в котором уже оформился I ярус выс. 22 м (Ø до 42 см), но еще сохранился подрост выс. 11-18 м (средний Ø 15 см). Насаждение имело вид узкой (4-5 м) ленты, занимавшей прирусловый вал старицы. Во II ярусе и подлеске - примесь ветлы (выс. 5-12 м), березы (выс. 9 м) и Salix viminalis (выс. 5-7 м).

Оп. 12: редина в неглубоком межгривном понижении в пределах крупного однородного контура бывшего осокорника. Это пример полного распада древостоя, который не сопровождается формированием насаждения иного состава. На контуре много сухостоя и отмирающего осокоря выс. 25-27 м (Ø 45 см), кроны которого слабо облиствены до выс. 18-20 м. В нижнем ярусе рассеяны отдельные ветлы выс. 11-18 м (Ø 28 см), ивы (Salix dasyclados) выс. 8 м, подрост березы выс. 9 м и куртины тополя белого выс. 5-6 м. На некоторых участках (за пределами УП) повален даже сухостой и осокорник заместился влажным слабо закустаренным (Rosa majalis, реже Frangula alnus, Ribes nigrum, Padus avium, Viburnum opulus) разнотравно-вейниковым (Calamagrostis canescens) лугом.

Оп. 13: ветлово-березово-осокоревый $\left(5 \mathrm{~T}_{\text {ч }} 3 \mathrm{5}_{2} \mathrm{И}_{6}\right)$ лес кустарниково-разнотравный, расположен на гребне широкой гривы. В I ярусе - осокорь и частично ветла, во II ярусе - береза и ветла. За пределами УП отмечен единичный подрост ели (выс. 2,3 и 2,7 м) и сосны (выс. 1,1 и 7 м).

Оп. 14: осокорник разнотравный на гребне той же гривы, но дальше от Оби. Состав древостоя: I ярус (выс. 22-24 м) - 10Т ч + Б, ІІ ярус (выс. 10-15 м) - 9Т ч 1 Б+С.

Оп. 15: распадающийся осокорник $\left(10 \mathrm{~T}_{4}+Б+И_{6}\right)$ кустарниково-разнотравный на плоском гребне пойменной гривы. Высота деревьев 25-27 м, тополя не очень толстые, но уже с полумертвыми кронами. Много сухих стволов осокоря, обломленных на выс. 2,5-10 м, много стволов лежит на почве либо нависает над ней.

Оп. 16: березово-тополевый $\left(1 \mathrm{~T}_{4} 8 \mathrm{~T}_{6} 15\right)$ лес кустарниково-разнотравный. Осокорь представлен как перестойными экземплярами (самые высокие деревья на УП), так и тонким интенсивно отмирающим жердняком выс. до 12 м. Последний редко отмечается в перестойных осокорниках. Вероятно, это результат вторичного подсева после одного из особо высоких половодий, в ходе которого поверхность почвы была обильно перекрыта новым аллювием. Во ІІ ярусе, довольно хорошо выраженном, доминирует подрост тополя белого.

Оп. 17: топольник $\left(6 \mathrm{~T}_{6} 2 \mathrm{~T}_{\mathrm{c}} 1 \mathrm{~T}_{\mathrm{q}} 15\right)$ кустарниково-разнотравный на гребне широкой гривы. Отмирающий осокорь почти полностью замещен тополями белым и сереющим. На УП отмечено 7 экз. сосны выс. 3,5-5 м, возраст 18 лет. Яблоня (Malus baccata) - с плодами.

Оп. 18: крупный контур распадающегося осокорника кустарниково-разнотравного с подростом пород-преемников. Выдел занимает широкое выровненное пространство между гребнями пойменных грив. Состав древостоя $4 \mathrm{~T}_{\text {ч }} 2 \mathrm{~T}_{6} 2 \mathrm{C} 2$ Б. Высота осокоря 27-28 м, кроны облиствены на выс. 18-24 м. Высота прочих пород различна: береза - 18-24 м, тополь бе- 
Таблица 2. Асc. Anemonidio dichotomi-Populetum nigrae: субасс. A. d.-P. n. typicum (11) и A. d.-P. $\boldsymbol{n}$. rubetosum saxatilis (13-18, 20-22); редины на месте распавшихся осокорников $(12,19)$

Table 2. Ass. Anemonidio dichotomi-Populetum nigrae: subass. A. d.-P. n. typicum (11) and A. d.-P. n. rubetosum saxatilis (13-18, 20-22); large glades on the places of decomposed black poplar stands $(12,19)$

\begin{tabular}{l|c|c|c|c|c|c|c|c|c|c|c|c}
\hline \multicolumn{1}{c|}{ Номер описания } & 11 & 12 & 13 & 14 & 15 & 16 & 17 & 18 & 19 & 20 & 21 & 22 \\
\hline Близость к Оби, ранг & 1 & 7 & 2 & 3 & 6 & 8 & 9 & 11 & 12 & 15 & 18 & 19 \\
\hline Форма поверхности & нак & вог & вог & нак & нак & гор & гор & вог & гор & нак & гор & гор \\
\hline Площадь описания, м ${ }^{2}$ & 100 & 50 & 100 & 100 & 100 & 100 & 100 & 100 & 50 & 100 & 100 & 100 \\
\hline Возрастное состояние $\mathrm{T}_{\text {ч }}$ & при & ред & при & при & рас & пер & пер & рас & ред & рас & сух & пер \\
\hline ОПП древостоя А1+А2, \% & 50 & 5 & 60 & 45 & 20 & 50 & 50 & 25 & 5 & 30 & 50 & 30 \\
\hline ОПП древостоя А1, \% & 45 & 5 & 40 & 40 & 15 & 35 & 50 & 12 & 3 & 15 & 40 & 30 \\
\hline ОПП древостоя А2, \% & 10 & + & 25 & 10 & 6 & 20 & нд & 14 & 2 & 20 & 13 & 2 \\
\hline ОПП подлеска, \% & 5 & 15 & 15 & 10 & 35 & 25 & 20 & 20 & 15 & 25 & 30 & 35 \\
\hline ОПП травостоя, \% & 45 & 50 & 20 & 50 & 35 & 25 & 25 & 70 & 50 & 45 & 30 & 45 \\
\hline Число видов сосудистых & 43 & 22 & 32 & 40 & 40 & 33 & 39 & 49 & 24 & 51 & 44 & 36 \\
\hline
\end{tabular}

A1 Populus nigra

A2 Populus nigra

A2 Betula pendula

A1 Betula pendula

A1 Populus alba

A2 Populus alba

A1 Populus $\times$ canescens

A2 Pinus sylvestris

A1 Pinus sylvestris

A1, A2 Salix alba

B Pinus sylvestris

B Betula pendula

B Populus alba

Anemonidium dichotomum

Ptarmica cartilaginea

Lathyrus palustris

Rubus saxatilis

B Rosa acicularis

B Crataegus sanguinea

Agrimonia pilosa

Д. в. союза Equiseto hyemalis-Populion nigrae и класса Salicetea purpureae

B Swida alba

B Rosa majalis

Lysimachia vulgaris

B Ribes hispidulum

Equisetum arvense

Poa palustris

Poa angustifolia

Agrostis gigantea

Filipendula ulmaria

Hieracium umbellatum

\begin{tabular}{|c|c|c|c|c|c|c|c|c|c|c|}
\hline 4 & 1 & 4 & 4 & 3 & 1 & 1 & 1 & 1 & 1 & + \\
\hline 2 & . & . & 2 & . & 1 & . & . & . & . & . \\
\hline+ & . & 3 & 1 & . & 1 & . & . & 1 & 1 & . \\
\hline$\cdot$ & . & . & + & 1 & 2 & 2 & 2 & . & 1 & 3 \\
\hline . & . & . & . & . & 3 & 4 & . & . & 2 & 3 \\
\hline . & . & . & . & . & 3 & . & 2 & . & . & 2 \\
\hline . & . & . & . & . & $\cdot$ & 2 & . & $\cdot$ & . & . \\
\hline . & . & . & + & . & $\cdot$ & $\cdot$ & 2 & . & 3 & + \\
\hline . & . & $\cdot$ & . & . & $\cdot$ & . & . & $\cdot$ & 1 & 2 \\
\hline 1 & + & 2 & . & 1 & . & . & . & . & . & . \\
\hline$\cdot$ & + & . & . & . & + & 1 & 1 & $\cdot$ & 1 & + \\
\hline$\cdot$ & . & $\cdot$ & + & . & $\cdot$ & + & 2 & 1 & . & . \\
\hline . & + & . & + & . & . & . & + & . & . & . \\
\hline
\end{tabular}

Д. в. acc. Anemonidio dichotomi-Populetum nigrae

$$
\begin{array}{rr|rrrrrrrrrr}
1 & + & + & + & 2 & 1 & + & 2 & 2 & 2 & . & 1 \\
+ & + & \cdot & + & . & . & . & + & 1 & . & . & + \\
+ & + & \cdot & . & . & . & . & . & 1 & + & . &
\end{array} .
$$

Д. в. субасс. A. d.-P. $n$. rubetosum saxatilis

$$
\begin{array}{ll|llllllllll}
\cdot & 2 & 2 & \cdot & 1 & 2 & 2 & 1 & 2 & 2 & 3 & 3
\end{array}
$$$$
\begin{array}{lll|llllllllll}
1 & 1 & 1 & 1 & 1 & + & 1 & 1 & 1 & 1 & 1 & 2 \\
1 & 1 & . & 1 & 2 & 1 & 1 & 2 & 1 & 2 & + & 2 \\
1 & 1 & + & . & + & 1 & + & 2 & 2 & 1 & + & . \\
+ & . & 2 & + & 1 & 1 & 1 & + & . & + & 1 & 1 \\
1 & . & + & + & + & + & + & + & . & . & + & + \\
1 & 1 & . & . & . & . & . & + & + & + & + & +
\end{array}
$$

Д. в. класса Brachypodio pinnati-Betuletea pendulae

$$
\begin{array}{|ll|llllllllll}
+ & \cdot & + & 1 & 1 & 1 & + & 1 & + & 1 & + & 1 \\
\cdot & \cdot & + & 1 & 1 & 1 & 1 & 1 & + & + & + & 1 \\
1 & 1 & \cdot & \cdot & + & 1 & + & 1 & 1 & 1 & + & + \\
1 & \cdot & \cdot & + & . & 1 & + & + & . & + & + & +
\end{array}
$$


Окончание табл. 2

End Table 2

\begin{tabular}{|c|c|c|c|c|c|c|c|c|c|c|c|c|}
\hline Номер описания & 11 & 12 & 13 & 14 & 15 & 16 & 17 & 18 & 19 & 20 & 21 & 22 \\
\hline Calamagrostis epigeios & 1 & . & + & + & + & . & + & . & . & + & + & + \\
\hline Vicia cracca & 1 & . & . & . & + & . & . & + & . & + & + & + \\
\hline Vicia sepium & . & . & + & . & . & . & + & . & . & + & + & + \\
\hline Veronica longifolia & 1 & . & . & + & . & . & . & + & . & . & . & + \\
\hline Lactuca sibirica & . & . & + & 1 & 2 & . & . & . & . & . & . & . \\
\hline Kadenia dubia & . & . & . & . & . & . & . & + & + & + & . & . \\
\hline \multicolumn{13}{|c|}{ Д. в. класса Alnetea glutinosae } \\
\hline B Frangula alnus & 1 & 1 & + & + & + & 3 & 3 & 2 & 2 & 2 & 3 & 2 \\
\hline B Ribes nigrum & . & 1 & 1 & 1 & 1 & + & + & . & . & . & . & 1 \\
\hline Carex cespitosa & + & . & + & . & + & . & . & + & . & + & + & . \\
\hline \multicolumn{13}{|c|}{ Прочие виды } \\
\hline B Viburnum opulus & + & 2 & . & + & + & + & + & + & 1 & 1 & 1 & + \\
\hline Elytrigia repens & + & . & + & + & + & + & + & + & . & . & + & + \\
\hline B Padus avium & + & . & 1 & + & 3 & . & + & . & . & + & 1 & 1 \\
\hline Galium boreale & 1 & . & + & . & + & . & . & + & 2 & 1 & + & + \\
\hline Glechoma hederacea & . & . & 1 & . & . & 1 & + & 1 & . & 1 & + & + \\
\hline Lathyrus pratensis & 1 & . & . & . & + & + & . & + & . & 1 & + & + \\
\hline Ranunculus polyanthemos & . & . & + & + & . & 1 & + & + & . & 1 & + & . \\
\hline Equisetum pratense & . & 1 & . & . & . & . & 2 & 3 & 2 & 2 & + & . \\
\hline B Malus baccata & . & . & + & + & . & + & + & 1 & . & 1 & . & . \\
\hline B Sorbus sibirica & . & . & + & + & 1 & + & . & . & . & . & 1 & 1 \\
\hline Orthilia secunda & . & . & + & + & + & . & . & . & . & + & + & 1 \\
\hline Ranunculus repens & 1 & . & + & + & + & + & . & . & . & . & . & . \\
\hline Thalictrum flavum & + & . & . & + & + & . & . & + & 1 & . & . & . \\
\hline Rumex confertus & + & . & . & . & + & + & . & . & . & + & + & . \\
\hline Achillea millefolium & . & . & + & + & . & . & + & + & . & + & . & . \\
\hline Pyrola rotundifolia & . & . & . & 4 & 2 & . & . & . & . & . & 1 & 3 \\
\hline Prunella vulgaris & . & . & . & . & . & 1 & . & 3 & + & + & . & . \\
\hline Inula salicina & + & . & . & . & . & . & + & 1 & . & + & . & . \\
\hline Amoria repens & . & . & . & + & . & 1 & + & . & . & + & . & . \\
\hline B Salix bebbiana & . & . & . & . & . & + & + & + & . & + & . & . \\
\hline Pyrola minor & . & . & + & . & + & + & . & . & . & . & + & . \\
\hline Carex praecox & 1 & . & . & . & . & 1 & . & . & . & + & . & . \\
\hline Thalictrum simplex & + & . & . & . & . & . & . & + & . & + & . & . \\
\hline Viola montana & . & . & . & . & . & . & . & + & . & + & + & . \\
\hline Geum aleppicum & . & . & + & + & . & . & . & . & . & + & . & . \\
\hline Calamagrostis canescens & . & 4 & . & . & . & . & . & . & . & . & . & . \\
\hline
\end{tabular}

Примечание. С невысоким постоянством отмечены: А2 Abies sibirica 21(+); A2 Betula pubescens 12(+); Botrychium multifidum 19(+), 20(+); Bromopsis inermis 11(+), 22(+); Calystegia sepium 14(+); Calamagrostis purpurea 11(+); Carex acuta 11(1); Carex disticha 18(+); Cerastium holosteoides 17(+); Cirsium setosum 17(+); Dryopteris carthusiana 14(+); Equisetum hyemale 15(+), 20(+); Euphorbia virgata 20(+); Festuca pratensis 18(1), 20(1); Fragaria vesca 14(1), 21(1); Galium palustre 11(+), 12(1); Geranium sibiricum 14(+); Lycopus exaltatus 11(+); Lythrum salicaria 18(+); Maianthemum bifolium 22(+); Petasites spurius 11(+); Phalaroides arundinacea 11(1); A2 Picea obovata 21(+); B Picea obovata 20(1); A2 Pinus sibirica 21(+); B Pinus sibirica 14(1); C Pinus sibirica 13(+); C Populus alba 18(+); C Populus $\times$ canescens 13(+); B Populus tremula 17(+); Potentilla anserina 11(+), 18(+); Ranunculus auricomus 20(+); Ranunculus monophyllus 15(+); A2 Salix dasyclados 12(+); B Salix dasyclados 15(1); B Salix rosmarinifolia 18(+); B Salix viminalis 11(+); Sanguisorba officinalis 11(+); Scutellaria galericulata 14(+), 15(+); Sonchus arvensis 11(+); C Sorbus sibirica 18(+); B Spiraea salicifolia 14(+); Stachys palustris 11(+), 12(1); Stellaria longifolia 15(+); Tanacetum vulgare 15(+), 21(+); Taraxacum officinale 16(+); Veronica serpyllifolia 17(+), Полевые номера описаний: 11 - оп. 46/1; 12 - оп. 46/7c; 13 - оп. 46/2; 14 - оп. 46/3; 15 - оп. 46/7; 16 - оп. 46/7d; 17 - оп. 46/7e; 18 - оп. 46/8; 19 - оп. 46/8b; 20 - оп. 46/9; 21 - оп. 47/1; 22 - оп. 47/2. Даты описаний: 11-16 - 11.09.2009; 17-20 - 13.09.2009; 21-22 14.09.2009. ПП видов указано в баллах, см. раздел «Материалы и методы». Условные обозначения разъяснены под табл. 1. 
лый - 14-15 м, сосна - 10-15 м. ОПП невысокого подроста березы, сосны и тополя белого (выс. 2-6 м) - $15 \%$.

Оп. 19: обширная редина. Осокори почти полностью отмерли, подрост березы редок, кустарники располагаются куртинами, костяника в травостое - пятнами. В заметном обилии отмечаются элементы влажных пойменных лугов: Anemonidium dichotomum, Ptarmica cartilaginea, Lathyrus palustris.

Оп. 20: распавшийся осокорник, замещаемый тополем белым, сосной и березой, на периферии гребня широкой пойменной гривы. Несмотря на значительное участие осокоря в составе древостоя $\left(4 \mathrm{~T}_{4} 1 \mathrm{~T}_{6} 4 \mathrm{C1Б}\right)$, он представлен отмирающими экземплярами со слабым облиствением. Древостой разреженный, неравномерный по высоте (16-22 м). Высота деревьев I яруса: осокорь - 20-24 м, тополь белый - 18-20 м, береза - 13-20 м, сосна - 15-20 м (І ярус) и 7-13 м (II ярус). Высота подроста сосны до 6 м, ели - до 2,2-3,2 м.

Оп. 21: расположенный на гребне широкой гривы сосново-березово-белотополевый $\left(5 \mathrm{~T}_{6} 3\right.$ Б2С) лес кустарниково-разнотравный. Это пример сообщества, в котором осокорь полностью замещен породами-преемниками. На УП отмечено два сухостойных осокоря выс. 25-27 м (Ø 35 и 36 см), на одном из которых сохранились отдельные живые веточки. Высота прочих деревьев 18-22 м. Древесный полог рыхлый, с окнами, которые заполняют подрост деревьев либо кустарники. Диаметр тополя белого до 43 см, его подроста - до 16 см. Диаметр березы - до 30 см, сосны - до 33 см. Высота сосен 15-18 м, возраст от 30 (выс. 15 м) до 35 лет (выс. 18 м). Единично отмечается подрост ели и кедра выс. 10-11 м, за пределами УП наблюдается генеративный экземпляр пихты выс. 12-13 м. На почве много валежин осокоря, многие перегнили и почти сравнялись с поверхностью почвы. ОПП мхов на валеже - 2-3 \%.

Оп. 22: березово-тополевый $\left(4 \mathrm{~T}_{6} 2 \mathrm{~T}_{4} 4 Б\right)$ лес кустарниково-разнотравный на широком ровном пространстве. Высота древостоя 1824 м. Выборочно замерены диаметры: тополь белый - 37, 40, 49 см, осокорь - 27, 31, 36 см, береза - 14, 30, 31 см. ОПП мхов - $2 \%$. За пределами этой УП в I ярусе отмечена единичная сосна (Ø 35 см).

Ареал синтаксонов. Субасс. A. d.-P. $\boldsymbol{n}$. typicum распространена вниз по течению Оби (Таран, 2014) до Сургута (Таран, Тюрин, 2006) и Елизаровского государственного заказника (Таран и др., 2004). Субасс. $\boldsymbol{A}$. $\boldsymbol{d} . \boldsymbol{- P}$. $\boldsymbol{n}$. rubetosum saxatilis к настоящему времени выявлена только у г. Колпашево. Вероятно, ее распространение ограничено южнотаежным отрезком Оби, поскольку подтаежный отрезок занимает субасс. Equiseto hyemalisPopuletum nigrae betuletosum pubescentis Taran 1997, а лесостепной - субасс. Equiseto hyemalis-Populetum nigrae typicum Taran 1997 (Таран, 1997, 2015б).

Состав ценофлоры. Видовое богатство и ВН топольников Колпашевской излучины удобнее рассмотреть отдельно по субассоциациям и стадиям развития древостоя, сравнив имеющийся материал с опубликованными данными с севера Томской области (табл. 3).

Как видно из табл. 3, с севера на юг в тополевых лесах, относимых к субасс. $\boldsymbol{A}$. d.$P$. n. typicum, ВН сообществ возрастает с 31,6 до 41,0 вид/а. Еще выше она в топольниках субасс. $\boldsymbol{A}$. d.-P. n. rubetosum saxatilis: от 36 до 46 вид/а в разных группах описаний, а в среднем по субассоциации - 42,7 вид/а.

Видовое богатство костяничной субассоциации также значительно выше, чем типичной: 113 видов сосудистых в 17 описаниях (оп. 3-10, 13-18, 20-22) против 75 видов в 
Таблица 3. Сравнительная характеристика общего видового богатства, видовой насыщенности и дендрофлоры тополевых лесов р. Оби (acc. Anemonidio dichotomi-Populetum nigrae) в северной и центральной частях Томской области

Table 3. Comparative characteristic of total species richness, species saturation, and woody flora of the Ob River poplar forests (ass. Anemonidio dichotomi-Populetum nigrae) in the north and central parts of Tomsk Region

\begin{tabular}{|c|c|c|c|c|c|c|}
\hline Номер столбца & 1 & 2 & 3 & 4 & 5 & 6 \\
\hline Природная подзона & \multicolumn{2}{|c|}{ средняя тайга } & \multicolumn{4}{|c|}{ южная тайга } \\
\hline Административный район & Ал (c) & Ал (ю) & \multicolumn{4}{|c|}{ Колпашевский } \\
\hline Субассоциация & \multicolumn{3}{|c|}{ typicum } & \multicolumn{3}{|c|}{ rubetosum saxatilis } \\
\hline Стадия развития осокоря & при-спе & жер-пер & при-спе & спе-пер & при-пер & pac-cyx \\
\hline Число описаний & 8 & 7 & 3 & 8 & 5 & 4 \\
\hline Средняя ВН, вид/а & 31,6 & 34,1 & 41,0 & 45,2 & 36,0 & 46,0 \\
\hline Амплитуда ВН, вид/а & $27-37$ & $31-37$ & $32-48$ & $32-57$ & $32-40$ & $40-51$ \\
\hline Общее число видов сосудистых & 68 & 62 & 67 & 97 & 66 & 74 \\
\hline
\end{tabular}

Одноствольные деревья

Abies sibirica

Betula pendula

A, B Betula pubescens

C Betula pubescens

Picea obovata

A2, B Pinus sibirica

C Pinus sibirica

Pinus sylvestris

C Pinus sylvestris

Populus alba

Populus $\times$ canescens

Populus nigra

Populus tremula

Salix alba

\section{Кустовидные деревья}

Malus baccata

B Padus avium

C Padus avium

Salix dasyclados

Salix viminalis

Sorbus sibirica

C Sorbus sibirica

\section{Кустарники}

Crataegus sanguinea

Frangula alnus

Ribes hispidulum

Ribes nigrum

C Ribes nigrum

Rosa acicularis

Rosa majalis

C Rosa majalis

Salix cinerea

Salix bebbiana

Salix rosmarinifolia

Spiraea salicifolia
Встречаемость вида в наборе описаний, \%

\begin{tabular}{c|c|}
$\cdot$ & $\cdot$ \\
$\cdot$ & $\cdot$ \\
25 & 14 \\
25 & $\cdot$ \\
$\cdot$ & $\cdot$ \\
$\cdot$ & $\cdot$ \\
$\cdot$ & $\cdot$ \\
$\cdot$ & $\cdot$ \\
12 & $\cdot$ \\
$\cdot$ & $\cdot$ \\
$\cdot$ & $\cdot$ \\
100 & 100 \\
$\cdot$ & $\cdot$ \\
50 & 57
\end{tabular}

\begin{tabular}{c|}
$\cdot$ \\
33 \\
33 \\
$\cdot$ \\
$\cdot$ \\
$\cdot$ \\
$\cdot$ \\
$\cdot$ \\
$\cdot$ \\
33 \\
$\cdot$ \\
100 \\
$\cdot$ \\
67
\end{tabular}

25

100

38

100

38

50

13

13

50

50

100

13

25

40

25

40

\begin{tabular}{c|c|c|c|c|c}
. & $\cdot$ & 33 & 88 & 80 & 50 \\
50 & $\cdot$ & 67 & 100 & 80 & 75 \\
50 & 29 & $\cdot$ & $\cdot$ & $\cdot$ & $\cdot$ \\
62 & 14 & 67 & 25 & $\cdot$ & 25 \\
12 & 43 & 33 & $\cdot$ & $\cdot$ & $\cdot$ \\
. & $\cdot$ & $\cdot$ & 75 & 80 & 75 \\
12 & 14 &. &. &. &.
\end{tabular}

50

75

\begin{tabular}{c|c|c|c|c|c}
$\cdot$ & $\cdot$ & $\cdot$ & 88 & 60 & 75 \\
$\cdot$ & $\cdot$ & 100 & 75 & 100 & 100 \\
$\cdot$ & $\cdot$ & 67 & 100 & 100 & 100 \\
50 & $\cdot$ & 33 & 100 & 100 & 25 \\
$\cdot$. & 29 & $\cdot$ & $\cdot$ & $\cdot$ & $\cdot$ \\
$\cdot$ & $\cdot$ & $\cdot$ & 100 & 40 & 100 \\
100 & 29 & 67 & 100 & 80 & 100 \\
$\cdot$ & 43 & $\cdot$ & $\cdot$ & $\cdot$ & $\cdot$ \\
$\cdot$ & $\cdot$ & $\cdot$ & 25 & $\cdot$ & $\cdot$ \\
$\cdot$ & $\cdot$ & $\cdot$ & $\cdot$ & 40 & 50 \\
12 & $\cdot$ & $\cdot$ & $\cdot$ & $\cdot$ & 25 \\
. & $\cdot$ & $\cdot$ & $\cdot$ & 20 & $\cdot$
\end{tabular}


Окончание табл. 3

End Table 3

\begin{tabular}{|c|c|c|c|c|c|c|}
\hline Номер столбца & 1 & 2 & 3 & 4 & 5 & 6 \\
\hline Природная подзона & \multicolumn{2}{|c|}{ средняя тайга } & \multicolumn{4}{|c|}{ южная тайга } \\
\hline B Swida alba & 75 & 29 & 67 & 75 & 100 & 100 \\
\hline C Swida alba & 12 & 43 & . & . & . & . \\
\hline B Viburnum opulus & 25 & . & 67 & 100 & 80 & 100 \\
\hline C Viburnum opulus & . & 29 & . & . & . & . \\
\hline
\end{tabular}

Примечание. Ал (с) и Ал (ю) - соответственно север и юг Александровского р-на Томской области. Стадии развития осокоря: жер - жердняк, при - приспевание, спе - спелость, пер - перестойная, рас - распад, сух - сухостой. Состав групп описаний: 1 - оп. 1, 2, 5, 8-11, 13 (Таран, 2014); 2 - оп. 3, 4, 6, 7, 12, 14, 15 (Таран, 2014); 3 - оп. 1, 2, 11 (данная статья); 4 - оп. 3-10 (данная статья); 5 - оп. 13, 14, 16, 17, 22 (данная статья); 6 - оп. 15, 18, 20, 21 (данная статья). Если вид отмечен только в травяном ярусе, на что указывает индекс «С», эти описания учитываются отдельно от тех, где вид отмечен в древесном или кустарниковом ярусах (соответственно индексы А и В). Так, в столбце 1 для Padus avium указано: В Padus avium 50, С Padus avium 50. Это означает, что в половине описаний черемуха отмечена в кустарниковом ярусе, а в другой половине - только в травяном.

15 описаниях на севере Томской области (Таран, 2014)

Всего в составе топольников Колпашевской излучины отмечено 11 видов одноствольных деревьев, 5 видов кустовидных деревьев (Malus baccata, Padus avium, Salix dasyclados, Salix viminalis, Sorbus sibirica), 12 видов кустарников, 1 вид полукустарников (Rubus caesius) и 94 вида трав.

Участие мхов в составе колпашевских топольников по сравнению со среднетаежными, напротив, уменьшается. Так, в осокорниках сургутского отрезка поймы Оби отмечено 48 видов при средней ВН 16,0 (5-28) вид/а и среднем ОПП напочвенных мхов 2,3 \% (амплитуда ОПП: +-15 \%) (Дьяченко, Таран, 2011). В топольниках Колпашевской излучины те же показатели таковы: общее число видов мхов - 34, средняя $\mathrm{BH}-14,4$ (8-23) вид/а, среднее ОПП - 1,3\%, амплитуда ОПП -+-3\% (Дьяченко, Таран, 2011).

Типологическое разнообразие. Согласно А.Ф. Алехиной $(1970,1976)$, ценозы субасс. A. d.-P. n. typicum можно отнести к осокорникам осоковому (оп. 1) и разнотравному (оп. 2, 11). Осокорник осоковый на севере Томской области в последние десятилетия не отмечался (Таран, 2014), хотя ранее (Алехина, 1970) указывался как довольно обычный. Среди сообществ субасс. $\boldsymbol{A}$. d.-P. $\boldsymbol{n}$. rubetosum saxatilis только оп. 14 можно отнести к осокорнику разнотравному. Прочие описания относятся к кустарниково-разнотравным типам леса, в древостое которых на стадиях приспевания и спелости обычно доминирует осокорь. На более поздних стадиях породный состав усложняется (табл. 4).

Сукцессии тополевых лесов на обследованном сегменте поймы протекают весьма разнообразно, нередко в виде мозаики отдельных варьирующих по составу парцелл, поэтому их можно обрисовать лишь в самых общих чертах. Как правило, основная пионерная порода тополевых лесов - осокорь, однако в зависимости от условий заселения участка поймы в древостое может появляться значительная примесь ветлы. Заселяет осокорь гребни и склоны пойменных грив, а также межгривные понижения высокого уровня.

Уже на стадии приспевания во II ярусе древостоя осокорников бывает значительной примесь березы, хотя чистые осокорники, пожалуй, более обычны. Если на УП имеются локальные понижения, даже на гребнях грив может быть заметным участие ветлы. В некоторых спелых осокорниках значительна 
Таблица 4. Состав древостоя в тополевых лесах Колпашевской излучины в зависимости от стадии развития осокоря

Table 4. Relation between stand composition in the Kolpashevskaya Meander poplar forests and the developmental stage of black poplar

\begin{tabular}{|c|c|}
\hline Стадия развития осокоря & Состав древостоя (табличный номер описания) \\
\hline & Субасс. A. d.-P. n. typicum \\
\hline Приспевание & $10 \mathrm{~T}_{\mathrm{u}}+\mathrm{U}_{\tilde{6}}$ (оп. 11$)^{*}$ \\
\hline \multirow[t]{2}{*}{ Спелость } & $10 \mathrm{~T}_{\text {ч }}$ (оп. 1$)^{* *}, 8 \mathrm{~T}_{\mathrm{q}} 2 \mathrm{~T}_{6}$ (оп. 2$)^{*}$ \\
\hline & Субасс. A. d.-P. n. rubetosum saxatilis \\
\hline Приспевание & $10 \mathrm{~T}_{\mathrm{u}}+$ Б (оп. 14)*, $5 \mathrm{~T}_{\mathrm{u}} 3 \mathrm{Б} 2 \mathrm{~V}_{6}$ (оп. 13) \\
\hline Спелость & $10 \mathrm{~T}_{\text {ч }}$ (оп. 6), $10 \mathrm{~T}_{\text {ч }}+$ Б (оп. 5*), $8 \mathrm{~T}_{\text {ч }} 2$ Б (оп. 3) \\
\hline Перестой (начало отмирания) & 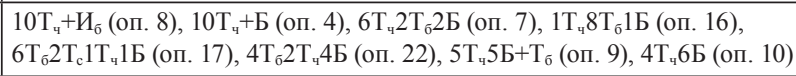 \\
\hline Распад (интенсивное отмирание) & $10 \mathrm{~T}_{\text {ч }}+\mathrm{Б}+\mathrm{U}_{6}$ (оп. 15 ), $4 \mathrm{~T}_{\text {ч }} 2 \mathrm{~T}_{6} 2 \mathrm{C} 2 \mathrm{Б}$ (оп. 18), $4 \mathrm{~T}_{4} 1 \mathrm{~T}_{6} 4 \mathrm{C} 1 Б$ (оп. 20) \\
\hline $\begin{array}{l}\text { Сухостой (полное замещение породами- } \\
\text { преемниками) }\end{array}$ & $5 \mathrm{~T}_{6} 3$ Б2C (оп. 21) \\
\hline
\end{tabular}

Примечание. Звездочкой, проставленной с правой стороны от закрывающей скобки, помечены описания осокорников разнотравных, двумя звездочками - описание осокорника осокового. Прочие описания относятся к кустарниковоразнотравным типам леса.

примесь тополя белого. В перестойных топольниках береза и тополь белый уже нередко совокупно доминируют над осокорем. На стадии распада осокоря в древостое обычно преобладают береза и тополь белый и нередко отмечается весомая примесь сосны и тополя сереющего.

Тополь белый, обильный на стадии распада осокоря, после полного выпадения последнего быстро вытесняется березой. Это противоречит его поведению в лесостепной и степной зоне, где он способен формировать достаточно долговечные белотополевые рощи, возобновляемые корневыми отпрысками (Таран, 1997, 2005б). Возможно, слабая устойчивость тополя белого объясняется тем, что у г. Колпашево он находится на северной границе своего ареала в пойме Оби.

В итоге в тыльной, наиболее старой части прирусловой зоны поймы на гривах формируются березовые леса, в древесном пологе которых могут сохраняться единичные экземпляры перестойных осокорей, спелых деревьев тополя белого и сосны, много реже - ели.
На самых легких грунтах топольники сменяются мелкоконтурными сосняками.

По-иному идет развитие топольников в межгривных понижениях. Если понижение в низовом конце дамбируется новыми аллювиальными наносами, его дренаж ухудшается. В этом случае подселение пород-преемников резко замедляется. По мере распада осокоря образуются редины, порой весьма обширные, в которых сохраняются небольшие фрагменты перестойных осокорников (оп. 4), а в целом преобладают участки с редким подростом березы, тополя белого и сосны (оп. 18). На самых сырых участках распавшихся осокорников редины (оп. 12, 19) сменяются влажными закустаренными лугами.

Тем не менее, в глубине поймы по краям широких грив, занятых уже большей частью березняками и парцеллами переходных к ним сосново-тополево-березовых ценозов, отмечаются узкие (10-20 м) ленты спелых (оп. 5, 6) и перестойных (оп. 7) осокорников. Вероятно, это результат повторного подселения осокоря, чему благоприятствует эрозия краевых 
зон широких грив транзитными водными потоками на пике наиболее сильных половодий. Этим же обусловлено появление мелкоконтурных осокорников осоковых (оп. 1) на днищах межгривных ложбин. После дальнейшего распада древостоя вторичных тополевых лент по краям наиболее старых грив сохраняются их мелкие фрагменты (оп. 8, 9). Небольшие участки березово-осокоревых лесов характерны также для высоких подмываемых берегов Оби (оп. 10).

Если рассматривать положение сукцессионных комплексов тополевых лесов на поперечнике поймы, можно выделить несколько широких полос, которые в целом располагаются на расстоянии 1,0-2,8 км от русла Оби. Непосредственно к руслу Оби выходит молодой пойменный сегмент, образованный в 1970-1990 гг. (Zavadskii et al., 2013: рис. 2). Он занят ивовыми (Salix alba, S. viminalis, S. triandra) лесами. Небольшой тополевый ценоз здесь отмечен только раз: 5-летний осокорник беспокровный на высокой песчаной гряде, открытой к руслу Оби. Высота осокоря составляла 1,6-2,5 м, ОПП травостоя - $3 \%$, в нем преобладали Equisetum arvense, Amoria repens, Calamagrostis epigeios.

Прочие тополевые насаждения располагаются на сегменте, образованном в 18901970 гг. Первый сукцессионный комплекс, включающий, главным образом, приспевающие и спелые насаждения, начинается в 1 км от русла Оби. Перечислим описания в порядке их удаленности от Оби: $11\left(10 \mathrm{~T}_{\mathrm{q}}+\mathrm{И}_{\sigma}\right) \rightarrow$ $13\left(5 \mathrm{~T}_{\mathrm{q}} 3 \mathrm{Б} 2 \mathrm{H}_{6}\right) \rightarrow 14\left(10 \mathrm{~T}_{\mathrm{u}}+\mathrm{Б}\right) \rightarrow 3\left(8 \mathrm{~T}_{\mathrm{q}} 2 \mathrm{Б}\right) \rightarrow$ $2\left(8 \mathrm{~T}_{\mathrm{q}} 2 \mathrm{~T}_{\sigma}\right) \rightarrow 15\left(10 \mathrm{~T}_{\mathrm{u}}+\mathrm{Б}+\mathrm{И}_{6}\right)$. ОП. $15-$ это распадающийся осокорник на краю гребня гривы, конечное звено данного комплекса.

Второй сукцессионный комплекс охватывает зону распавшихся осокорников. Последовательность характеризующих его УП такова: 12 (первая осокоревая редина в межгривной ложбине $) \rightarrow 16\left(1 \mathrm{~T}_{4} 8 \mathrm{~T}_{6} 1 Б\right) \rightarrow 17\left(6 \mathrm{~T}_{6} 2 \mathrm{~T}_{\mathrm{c}} 1 \mathrm{~T}_{\mathrm{q}} 1 Б\right) \rightarrow$ $4\left(10 \mathrm{~T}_{4}+\mathrm{Б}\right) \rightarrow 18\left(4 \mathrm{~T}_{4} 2 \mathrm{~T}_{6} 2 \mathrm{C} 2 \mathrm{Б}\right) \rightarrow 19$ (вторая осокоревая редина). На гривах этой зоны осокорь активно замещается тополями белым и сереющим, березой и сосной. Между оп. 12 и 16 отмечена парцелла с участием осины $\left(1 \mathrm{~T}_{\text {ч }} 7 \mathrm{Oc} 2 Б\right)$, но ее описание сделать не удалось. В межгривных понижениях высокого уровня смена пород идет медленнее, чем обычно, что приводит к образованию редин (оп. 12, 19), на фоне которых доживают фрагменты перестойных осокорников (оп. 4).

Третий сукцессионный комплекс объединяет старые гривы, где в основном завершилась смена топольников березняками (реже сосняками), но на ближних к Оби участках еще отмечаются парцеллы со сложными древостоями. По периферии этих грив, реже в межгривных ложбинах вновь отмечаются узкие ленты спелых осокорников вторичного подселения (оп. 1, 5, 6). На самых старых гривах комплекса сохранились лишь мелкие фрагменты перестойных осокоревых (оп. 8) и осокорево-березовых лесов (оп. 9). Взаимное расположение описаний по мере удаления от Оби таково: $1\left(10 \mathrm{~T}_{\text {ч }}\right) \rightarrow 5\left(10 \mathrm{~T}_{\mathrm{q}}+\mathrm{Б}\right) \rightarrow$ $20\left(4 \mathrm{~T}_{\mathrm{y}} 1 \mathrm{~T}_{6} 4 \mathrm{C1Б}\right) \rightarrow 6\left(10 \mathrm{~T}_{\mathrm{u}}\right) \rightarrow 7\left(6 \mathrm{~T}_{\mathrm{y}} 2 \mathrm{~T}_{6} 2 \mathrm{Б}\right) \rightarrow$ $21\left(5 \mathrm{~T}_{6} 3 \mathrm{Б} 2 \mathrm{C}\right) \rightarrow 22\left(4 \mathrm{~T}_{6} 2 \mathrm{~T}_{4} 4 \mathrm{Б}\right) \rightarrow 8\left(10 \mathrm{~T}_{\mathrm{\varphi}}+И_{6}\right) \rightarrow$ $9\left(5 \mathrm{~T}_{\mathrm{\varphi}} 5 \mathrm{~b}+\mathrm{T}_{6}\right)$.

\section{Заключение}

В синтаксономическом отношении тополевые леса реки Оби, обследованные на крупном пойменном массиве, Колпашевской излучине, относятся к асс. Anemonidio dichotomi-Populetum nigrae Taran 1993 (союз Equiseto hyemalis-Populion nigrae Taran 1997, порядок Salicetalia purpureae Moor 1958, класс Salicetea purpureae Moor 1958). Они разделяются на две субассоциации.

Субасс. A. d.-P. n. typicum Taran 1993, господствующая в подзоне средней тайги, на 
Колпашевской излучине редка, что подчеркивает ее экстразональный характер. Сообщества этой субассоциации занимают наиболее влажные местообитания. В типологическом отношении они представлены осокорниками осоковым и разнотравным.

Субасс. A. d.-P. n. rubetosum saxatilis Taran subass. nov. характерна для подзоны южной тайги. Именно ее сообщества преобладают на Колпашевской излучине. В типологическом отношении костяничная субассоциация представлена разнообразными вариантами кустарниково-разнотравных типов леса: осокорниками, белотопольниками, березовотополевыми лесами и другими вариантами. И только раз в составе субассоциации отмечен разнотравный осокорник.

По сравнению с осокорниками подзоны средней тайги, топольники Колпашевской излучины богаче видами сосудистых. Средняя видовая насыщенность Колпашевских топольников, учтенная от стадии приспевания до стадии распада осокоря, составляет 41,0 вид/а в типичной субассоциации, 42,7 вид/а - в костяничной, общее видовое богатство обеих субассоциаций - 123 вида. В подзоне средней тайги, в осокорниках Александровского района Томской области, те же показатели равнялись 32,8 вид/а и 75 видов соответственно.

Также в тополевых лесах Колпашевской излучины выявлены 1 вид печеночников (Aneura pinguis) и 34 вида мхов. Средняя видовая насыщенность мхами составляет 14,4 вид/a, амплитуда видовой насыщенности - 8-23 вид/а.

Общее направление сукцессии тополевых лесов Колпашевской излучины выражается в смене осокорников березняками, а на самых легких песчаных грунтах - мелкоконтурными сосняками. На средних стадиях сукцессии значительную роль играет тополь белый, иногда с примесью тополя сереющего. У г. Колпашево тополь белый не образует устойчивых, долговечных ценозов, что, вероятно, объясняется его положением на крайней северной границе ареала в пойме Оби.

\section{Благодарности / Acknowledgements}

Г.С. Таран премного благодарен сотрудникам лаборатории эрозии почв и русловых процессов географического факультета МГУ (г. Москва) и особенно к. г. н. В.В. Суркову за большую помощь в организации исследований на Колпашевской излучине р. Оби, д. б. н. В.А. Бакалину (БСИ ДВО РАН, г. Владивосток) - за определение печеночника Aneura pinguis.

G.S. Taran is very grateful to the staff of the Laboratory of Soil Erosion and Fluvial Processes at the Faculty of Geography of Moscow State University (Moscow), especially to V.V. Surkov, Cand. Sc., for their great help in organization of research on the Kolpashevskaya bend of the Ob' River and to V.A. Bakalin, Dr. Sc. (Botanical Garden - Institute FEB RAS, Vladivostok), for identification of the liverwort Aneura pinguis.

\section{Список литературы / References}

Алехина А.Ф. (1970) Осокорники поймы р. Оби. Изв. СО АН СССР. Сер. биол. наук, 2: 5358 [Alekhina A.F. (1970) Black poplar forests of the Ob River floodplain. Proceedings of the Siberian Branch of the Academy of Sciences of the USSR. Series of Biological Sciences [Izv. SO AN SSSR. Ser. biol. nauk], 2: 53-58 (in Russian)]

Алехина А.Ф. (1971) Тополевые леса поймы Оби. Эффективность использования лесных ресурсов и их восстановление в Западной Сибири. Новосибирск, НТО лесн. пром-ти и лесн. 
хо3-ва, с. 149-155 [Alekhina A.F. (1971) Poplar forests of the Ob floodplain. Efficiency of use of forest resources and their recovery in Western Siberia. Novosibirsk, Scientific and Technical Society of Forest Industry and Forestry, p. 149-155 (in Russian)]

Алехина А.Ф. (1976) Закономерности размещения топольников в пойме Оби и повышение их хозяйственной роли. Повышение эффективности лесного хозяйства в Западной Сибири. Новосибирск, Наука, с. 137-142 [Alekhina A.F. (1976) Patterns of distribution of poplar forests in the Ob floodplain and upsurge of their economic role. Upsurge of effiency of forestry in Western Siberia. Novosibirsk, Nauka, p. 137-142 (in Russian)]

Боотсма М.К., Блейтен В., Лапшина Е.Д., Ван дер Перк М., де Смидт Й.Т. (1995) Типология экосистем ненарушенной части водосборной территории бассейна Оби на юго-востоке Западной Сибири. Сибирский экологический журнал, 2 (4): 316-333 [Bootsma M.C., Bleuten W., Lapschina E.D., Van der Perk M., de Smidt J.T. (1995) Ecosystems typology of an undisturbed part of the Ob River catchment area in Southeastern West Siberia (Russia). Siberian Journal of Ecology, 2 (4): 316-333]

Дьяченко А.П., Таран Г.С. (2011) К бриофлоре пойменных лесов реки Оби в подзоне южной тайги. Вестник Томского государственного университета. Биология, 3 (15): 75-91 [Dyachenko A.P., Taran G.S. (2011) On bryoflora of the Ob River floodplain forests in south taiga subzone. Tomsk State University Journal of Biology, 3 (15): 75-91 (in Russian)]

Зверев А.А. (2007) Информационные технологии в исследованиях растительного покрова. Томск, ТМЛ-Пресс, 304 с. [Zverev А.А. (2007) Information technologies in study of vegetation cover. Tomsk, TML-Press, 304 p. (in Russian)]

Ильина И.С., Лапшина Е.И., Лавренко Н.Н., Мельцер Л.И., Романова Е.А., Богоявленский Б.А., Махно В.Д. (1985) Растительный покров Западно-Сибирской равнины. Новосибирск, Наука, 251 с. [Ilyina I.S., Lapshina Ye.I., Lavrenko N.N., Meltser L.I., Romanova Ye.A., Bogoyavlenskiy B.A., Makhno V.D. (1985) Vegetation cover of West-Siberian plain. Novosibirsk, Nauka, 251 p. (in Russian)]

Львов Ю.А. (1963) К характеристике растительности поймы реки Оби. Природа поймы реки Оби и ее хозяйственное освоение. Томск, Изд-во Том. ун-та, с. 258-267 [Lvov Yu.A. (1963) On the description of the $\mathrm{Ob}$ River floodplain vegetation. Nature of the Ob River floodplain and its economic assimilation. Tomsk, Tomsk State University, p. 258-267 (in Russian)]

Николаев И.В. (2012) Оценка затопляемости пойм больших рек во время половодья (на примере реки Оби). География и природныле ресурсы, 4: 175-179 [Nikolayev I.V. (2012) Assessing the inundation behavior of floodplains of large rivers during a flood (exemplified by the Ob River). Geography and Natural Resources [Geografiya i prirodnyye resursy], 4: 175-179 (in Russian)]

Таран Г.С. (1993) Синтаксономический обзор лесной растительности поймы средней Оби (александровский отрезок). Сибирский биологический журнал, 6: 85-91 [Taran G.S. (1993) Syntaxonomical survey of forest vegetation of middle $\mathrm{Ob}$ floodplain (Aleksandrovskoye piece). Siberian Journal of Biology [Sibirskiy biologicheskiy zhurnal], 6: 85-91 (in Russian)]

Таран Г.С. (1997) К синтаксономии тополевых лесов Обь-Иртышского бассейна. Ботанические исследования Сибири и Казахстана. Bыn. 3. Барнаул, Изд-во АГУ, с. 70-76 [Taran G.S. (1997) On syntaxonomy of poplar forests of Ob and Irtysh basin. Botanical investigations of Siberia and Kazakhstan. Iss. 3. Barnaul, Altai State University, p. 70-76 (in Russian)] 
Таран Г.С. (2005а) Флора Вах-Тымского отрезка поймы Оби. Биологические ресурсы и природопользование. Bып. 8. Сургут, Дефис, с. 3-27 [Taran G.S. (2005a) Flora of Vakh-Tym segment of Ob River floodplain. Biological resources and nature management. Iss. 8. Surgut, Defis, p. 3-27 (in Russian)]

Таран Г.С. (2005б) К синтаксономии пойменных лесов (Salicetea purpureae Moor 1958) рек Иртыш и Черный Иртыш. Растительность России, 7: 82-92 [Taran G.S. (2005b) On syntaxonomy of floodplain forests (Salicetea purpureae Moor 1958) of the Irtysh and Black Irtysh rivers. Vegetation of Russia [Rastitelnost Rossii], 7: 82-92 (in Russian)]

Таран Г.С. (2014) Осокорники поймы Оби на севере Томской области (Западная Сибирь, Россия). Вестник Томского государственного университета. Биология, 2 (26): 74-89 [Taran G.S. (2014) Black poplar forests of the Ob River floodplain on the north of Tomsk oblast (Western Siberia, Russia). Tomsk State University Journal of Biology, 2 (26): 74-89 (in Russian)]

Таран Г.С. (2015a) Редкие варианты осокорников на севере Томской области. Вестник КрасГАУ, 2: 212-215 [Taran G.S. (2015a) Rare variants of black poplar stands on the north of the Tomsk Region. Bulletin of KrasGAU, 2: 212-215 (in Russian)]

Таран Г.С. (2015б) К синтаксономии лавротопольников Алтайского края. Вестник КрасГAУ, 7: 200-205 [Taran G.S. (2015b) To the syntaxonomy of Populus laurifolia forests of the Altai Territory. Bulletin of KrasGAU, 7: 200-205 (in Russian)]

Таран Г.С., Седельникова Н.В., Писаренко О.Ю., Голомолзин В.В. (2004) Флора и растительность Елизаровского государственного заказника (нижняя Обь). Новосибирск, Наука, 212 c. [Taran G.S., Sedelnikova N.V., Pisarenko O.Yu., Golomolzin V.V. (2004) Flora and vegetation of Yelizarovskiy State Reserve (the lower Ob). Novosibirsk, Nauka, 212 p. (in Russian)]

Таран Г.С., Тюрин В.Н. (2006) Очерк растительности поймы Оби у города Сургута. Биологические ресурсы и природопользование. Bыл. 9. Сургут, Дефис, с. 3-54 [Taran G.S., Tyurin V.N. (2006) Survey of the Ob flodplain vegetation near Surgut city. Biological resources and nature management. Iss. 9. Surgut, Defis, p. 3-54 (in Russian)]

Черепанов С.К. (1995) Сосудистые растения России и сопредельных государств (в пределах бывшего СССР). СПб., Мир и Семья-95, 992 с. [Czerepanov S.K. (1995) Vascular plants of Russia and adjacent States (the Former USSR). St. Petersburg, Mir i Semya-95, 992 p. (in Russian)]

Ignatov M.S., Afonina O.M., Ignatova E.A., Abolina A., Akatova T.V., Baisheva E.Z., Bardunov L.V., Baryakina E.A., Belkina O.A., Bezgodov A.G., Boychuk M.A., Cherdantseva V.Ya., Czernyadjeva I.V., Doroshina G.Ya., Dyachenko A.P., Fedosov V.E., Goldberg I.L., Ivanova E.I., Jukoniene I., Kannukene L., Kazanovsky S.G., Kharzinov Z.Kh., Kurbatova L.E., Maksimov A.I., Mamatkulov U.K., Manakyan V.A., Maslovsky O.M., Napreenko M.G., Otnyukova T.N., Partyka L.Ya., Pisarenko O.Yu., Popova N.N., Rykovsky G.F., Tubanova D.Ya., Zheleznova G.V., Zolotov V.I. (2006) Check-list of mosses of East Europe and North Asia. Arctoa, 15: 1-130

Weber H.E., Moravec J., Theurillat J.-P. (2000) International code of phytosociological nomenclature. $3^{\text {rd }}$ ed. Journal of Vegetation Science, 11 (5): 739-768

Zavadskii A.S., Il'yasov A.K., Ruleva S.N., Surkov V.V., Turykin L.A., Chalov R.S. (2013) The evolution of the Kolpashevskaya meander of the $\mathrm{Ob}^{\prime}$ and ongoing hazardous manifestations of channel processes. Geography and Natural Resources, 34(1): 26-33 